\title{
トラック荷室上部に設置したウィンドディフレクタの抗力低減効果
}

\author{
保木本 聖*1，小林 佳弘 ${ }^{* 2}$, 巟山 秀晴 ${ }^{* 2}$, 高橋 易資 ${ }^{* 2}$
}

\section{Reduction effects of drag by a wind deflector attached on a truck container}

\author{
Satoshi HOKIMOTO*1, Yoshihiro KOBAYASHI ${ }^{* 2}$, \\ Hideharu KOYAMA $^{* 2}$ and Yasushi TAKAHASHI ${ }^{* 2}$ \\ ${ }^{* 1}$ Tokyo Denki Univ. Dept. of Mechanical Engineering, Graduate School of Engineering \\ 5 Senjyu-Asahi-cho, Adachi-ku, Tokyo, 120-8551, Japan \\ ${ }^{*}$ Tokyo Denki Univ. Dept. of Mechanical Engineering, \\ 5 Senjyu-Asahi-cho, Adachi-ku, Tokyo, 120-8551, Japan
}

Received 29 September 2013

\begin{abstract}
Recently, reduction of $\mathrm{CO}_{2}$ emissions from automobiles is carried out in the world. The improvement in aerodynamics and reduced in $\mathrm{CO}_{2}$ emissions have been realized with passenger cars. However, there is still some room for improvement between trucks and trailers in aerodynamics. In this study, a wind deflector attached on the container of a truck was proposed to reduce the drag. To investigate the effects, the drag and flow patterns over a small-scale truck model were measured in a small wind tunnel. Furthermore, the drag, flow patterns, and pressure distributions of a full-scale truck model were examined at a highway driving condition by Computational Fluid Dynamics. It was found that the drag can be reduced without losing container space by the wind deflector attached on the container. The maximum decreasing ratio of drag was $3.4 \%$. As the reason of the drag reduction, it was found that the wind deflector reduces size of wake flow and increases static pressure behind the vehicle.
\end{abstract}

Key words : Heavy duty, Truck, Trailer, Drag reduction, Vortex, PIV, CFD

\section{1. 緒言}

近年，地球温暖化などの観点から，世界規模の $\mathrm{CO}_{2}$ 排出量削減が求められており，自動車においてもその対策 が行われている．国内における $\mathrm{CO}_{2}$ 排出量割合のおよそ $19 \%$ は運輸部門が占めており(環境省, 2011), 乗用車に 関しては，エンジン性能向上やモータとのハイブリッド車の普及，ボディ形状の空力性能改善など，燃費性能向 上が計られてきた. しかし貨物自動車（トラック）の場合, 乗用車と同様にエンジン性能向上やハイブリッド車 の普及は進んでいるものの，ボディ形状に関しては荷物の積載量や積載の利便性が重視され，乗用車と比べると 空力性能の改善はあまり進んでいない，運輸部門の中でトラックの占める割合は大きく，抗力低減による実走燃 費向上は，日本全体の $\mathrm{CO}_{2}$ 排出量削減に大きく貢献するものと思われる.

トラック抗力低減の手法としては，キャビン上部に取り付けるエアディフレクタが普及している．これは，キ ヤビンと荷室との段差を滑らかに繋げ, 圧力抵抗を低減させる効果がある. しかし，トラックの空力改善として， 他の対策手法の実用例は殆ど見られない，特に，荷室後方に発生する大規模の再循環流れに起因する圧力抵抗な ど，車体後部に注目した対策は，殆ど行われていない。

トラック荷室は，多くの場合箱型（直方体）であり，後面は進行方向に対して垂直である．箱型形状の下流域 には, 再循環流れにより大きな負圧領域が発生しており, 後方へ向けて傾斜面を持った形状の抗力が低いことは, 古くから知られている(農沢, 佐藤, 2009). そこで, 図 1(a) に示寸ように, トラック荷室の一部に傾斜面を設け,

No.13-00722 [DOI: 10.1299/transjsme.2014fe0115]

${ }^{* 1}$ 正員, 東京電機大学工学部研究生（現 千葉大学大学院 工学研究科 人工システム科学専攻）

*2 2 正員, 東京電機大学工学部機械工学科（广120-8551 東京都足立区千住旭町 5 番)

E-mail of corresponding author: s_hokimoto_0726@yahoo.co.jp 
車体後方へ向けて絞り込むことにより，抗力を低減させることが出来ると考えられる．しかし荷室の一部をカッ ト寸る傾斜面は，荷室体積を減少させ，運送業者等トラックユーザーに受け入れられない，既存研究として，荷 室後部に “Boat tail” と呼ばれる導風板を設けることにより，荷室体積を減少させることなく抗力を低減させた例 がある(Browand and Radovich, 2005，土田他，2010). しかし，車体外に向けて尖った鋭利な形状は突起物と見なさ れる. 歩行者保護などの観点から柔軟な素材で作成しても，設置位置の都合上，道路運送車両法車両保安基準に そぐわず，実用化は困難である.

そこで本研究では, 大型自動車の車両規定最大高さ寸法 $3.8 \mathrm{~m}$ に着目し, 規定寸法内で荷室上部に設置出来, なおかつ既存のトラックの荷室に後付出来，荷室体積を減少させることなく抗力の低減が可能な手法として， 図 1 (b) に示すような荷室の上部後方に傾斜面を有したウィンドディフレクタを提案し, その効果の検証として, 1/32 スケールトラックモデルを用いた抗力測定および PIV（Particle Image Velocimetry）による流れの可視化を行 った，更に，実車スケールの実験は困難なため，実車走行条件でのウィンドディフレクタの抗力低減効果および トラック周り流れの検討を数值流体計算を用いて行った.

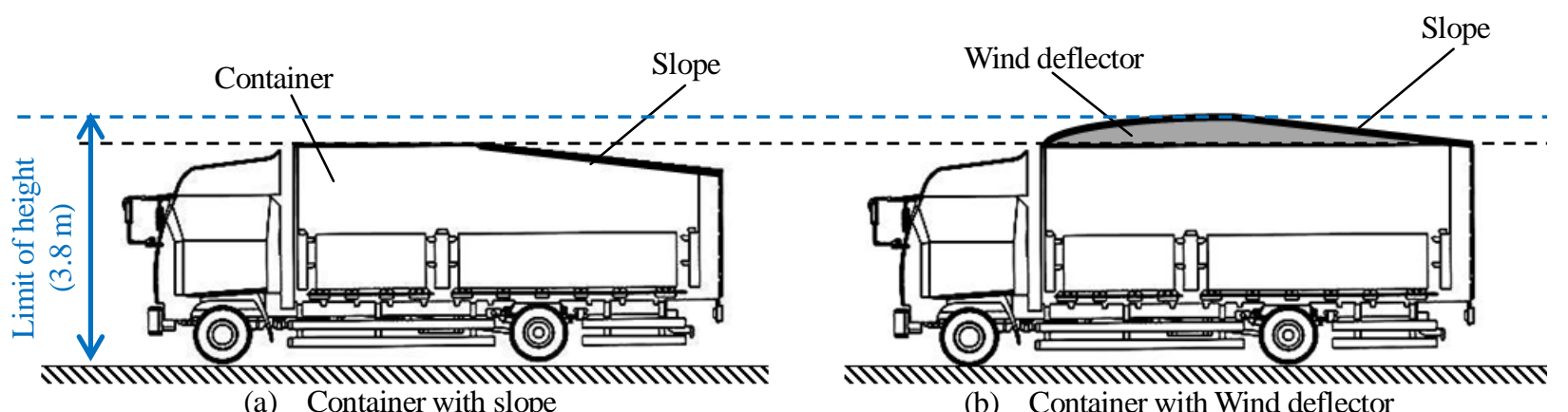

Fig. 1 Concept of a wind deflector on the truck.

\section{2. トラックモデルおよび荷室用ウィンドディフレクタ}

本研究では, 中型トラック（積載量 $: 4 \mathrm{t}$ ) を対象とした. トラックモデルおよびウィンドディフレクタの概 略図を図 2 に示す.

風洞実験には $1 / 32$ スケールモデルを, 数值流体計算には実車スケールモデルを用いた. $1 / 32$ スケールモデル は，日野レンジャー・ハイルーフウィングのプラスチックモデル（青島文化教材社）を用いた．実車スケールト ラックモデルはこれを 32 倍に拡大した. ウィンドディフレクタは, 図 2 に示すように, 進行方向に対し前後に二 つの傾斜角を設け，側面投影形状を山形とし，二つの傾斜角の成寸頂点は滑らかな曲面とし，荷室上部に装着し た. ここで前方傾斜角を $\theta_{f}$, 後方傾斜角を $\theta_{r}$ とする. またウィンドディフレクタ装着によるトラックモデルの 前面投影面積の増加率はウィンドディフレクタそのものの面積増加分であり, 前後の傾斜角によって異なる. 本 研究ではこの角度依存のある前面投影面積増加率を $\Delta S$ と定義した.

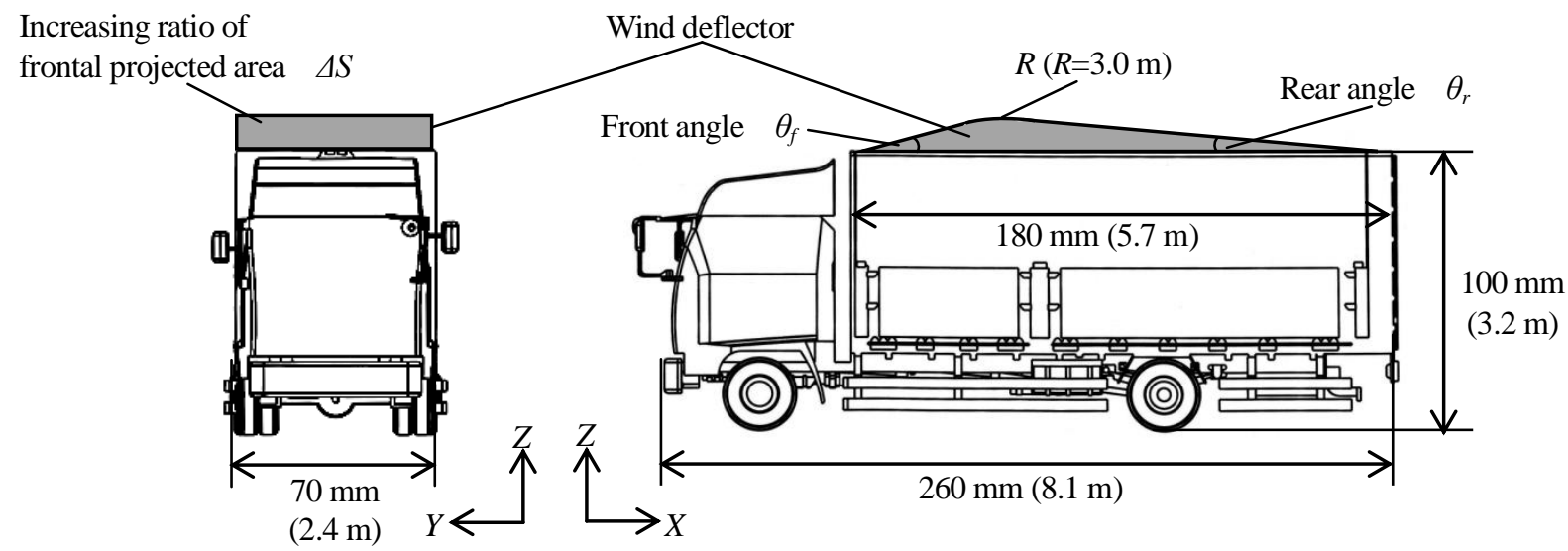

Fig. 2 Truck model and Wind deflector. 


\section{3. 実験装置および方法}

\section{$3 \cdot 1$ 実験用小型風洞}

図 3 に，本研究で用いた実験用小型風洞の概略図を示す。本風洞は，大気開放型吸い込み式であり，24メッシ ユ金網 5 枚を設置した整流部，正弦曲線を用いた絞り比 $4: 1$ の縮流部，そして $X=1000 \mathrm{~mm}, Y=500 \mathrm{~mm}, Z=500$ $\mathrm{mm}$ の試験部から構成される. 試験部は，風洞外側から流れを可視化するため，透明アクリル製とした. 試験部 中央における最大流速は $7.2 \mathrm{~m} / \mathrm{s}$, 最大乱れ強さは $2.7 \%$ あった.

\section{$3 \cdot 2$ 抗力測定装置および方法}

図 4 に，抗力測定装置の概略図を示す．抗力測定の際，トラックモデルのタイヤと床面間の摩擦抵抗を除くた め，上部からステンレス線（直径 $0.3 \mathrm{~mm}$ ）により 4 点吊りにし，トラックモデルを $1 \mathrm{~mm}$ 浮かした. 抗力の測定 のため前方にステンレス線を取り付け，滑車を介して試験部下部にあるロードセル（日章電機社，LMC）に接続 した. なお同ステンレス線に十分な張力を与えるため，後方にもステンレス線を取り付け，滑車を介して分銅を 吊るした. ロードセルから得られた信号は, 増幅器（日章電機社，DSA-100A）及びデータロガ（KEYENCE 社， NR-1000）を通してパソコンに接続した。 抗力測定では，風洞内流速ゼロ時のロードセル出力を抗力のゼロ点と し，風洞内に流速を与えた場合にロードセルに加わる張力増加分をトラックモデルにかかる抗力とした. 測定時 の流入流速は $7.2 \mathrm{~m} / \mathrm{s}$ とし，トラックモデル全長に基づくレイノルズ数 $R e$ は， $R e=1.23 \times 10^{5}$ である.

\section{3・3 PIV 計測装置および方法}

PIV システムの概略図を，図 5 および図 6 に示す。測定は，トラックモデル後方の $X-Z$ 断面（図 5）および $Y$ $Z$ 断面(図 6)の 2 箇所で行った. レーザシート光は, 波長 $532 \mathrm{~nm}$, 最大出力 $5 \mathrm{~W}$ の半導体励起固体レーザ(DANTEC 社, Raypower5000） と, 散光角 $5^{\circ}$ のラインジェネレータレンズを用いて形成した. なお $X-Z$ 面内の測定の際に は，傾斜角 $45^{\circ}$ の鏡を介して照射し， $Y-Z$ 面の測定の際には，側面から直接照射した．トレーサは超音波加湿器 (阪和社, Ms. ミスト ver.4）より発生させた平均粒径約 $7 \mu \mathrm{m}$ の水粒子を用い，試験部前方下部より供給した. ト レーサからの散乱光は, 高速度カメラ (IDT 社, XS-3) により撮影・記録し, データ処理には PIV 処理ソフト (IDT 社, Pro Vision）を用いた.

計測条件は，最大流速 $1.8 \mathrm{~m} / \mathrm{s}$ およびレーザシート光幅 $4 \mathrm{~mm}$ とし， $X-Z$ 面内の測定の際は，毎秒フレームレー ト 500 で 2000 フレーム， $Y-Z$ 面の測定の際は，毎秒フレームレート 800 で 2000 フレームとした. なおトラック モデル全長に基づくレイノルズ数 $R e$ は, $R e=3.08 \times 10^{4}$ である.

\section{4. 数值流体計算手法と計算条件}

実車走行を想定し，実車スケールのトラックモデルにて定常流数值流体計算を行った．計算コードには，直線 直交格子を用いたパーシャルセル法（Partial Cells in Cartesian coordinate method）を使用した。本計算コードは, 離散化手法に有限体積法，計算アルゴリズムに SIMPLE 法，乱流モデルに壁関数と低レイノルズ数型 $k-\varepsilon$ モデル を組み合わせたモデルを用いている。この乱流モデルは，高レイノルズ数領域では標準 $k-\varepsilon$ モデルと壁関数によ り計算し，そして壁関数が適用外となる低レイノルズ数領域の壁面近傍では低レイノルズ数型 $k-\varepsilon$ モデルを機能 させ，幅広い計算条件への対応を計ったものである. 本計算コードは，過去に基本的な流れ場をはじめ種々の条 件において実験結果との比較検証が行われており (高橋他, 2005, Takahashi, et al., 2007 and 2009, Ishima, et al., 2008), 1 / 4 スケールモデルの 3 次元 PIV 計測とパーシャルセル法計算コードによる車体周り流れの検証を行った研究例 もある(Ishima, et al., 2011). 今回はその結果を踏まえ, 実験困難なトラックの実車走行条件をパーシャルセル法計 算コードにて行った.

流入境界条件は, $100 \mathrm{~km} / \mathrm{h}$ 走行を想定した圧力境界条件を計算風洞入口および出口に与え, 乱れ強さは実車走 行を想定し $5 \%$ とした. このときトラックモデル全長を代表長さとしたレイノルズ数 $\operatorname{Re}$ は $1.21 \times 10^{7}$ である. 計算 風洞は $X=40 \mathrm{~m}, \quad Y=15 \mathrm{~m}, Z=15 \mathrm{~m}$ の直方体とし, トラックモデルの先端は風洞入口から $4 \mathrm{~m}$ に位置した. 計 
算格子はトラックモデル周りを $40 \mathrm{~mm}$, ウィンドディフレクタ周りを $10 \mathrm{~mm}$ とし, 遠方になるにつれて粗くした. 総格子数はおよそ 1400 万メッシュである.

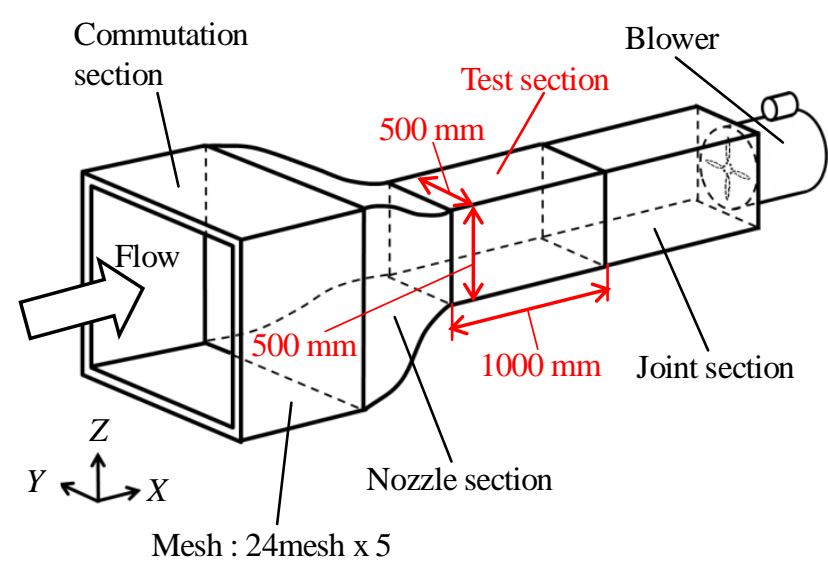

Fig. 3 Schematic diagrams of wind tunnel.

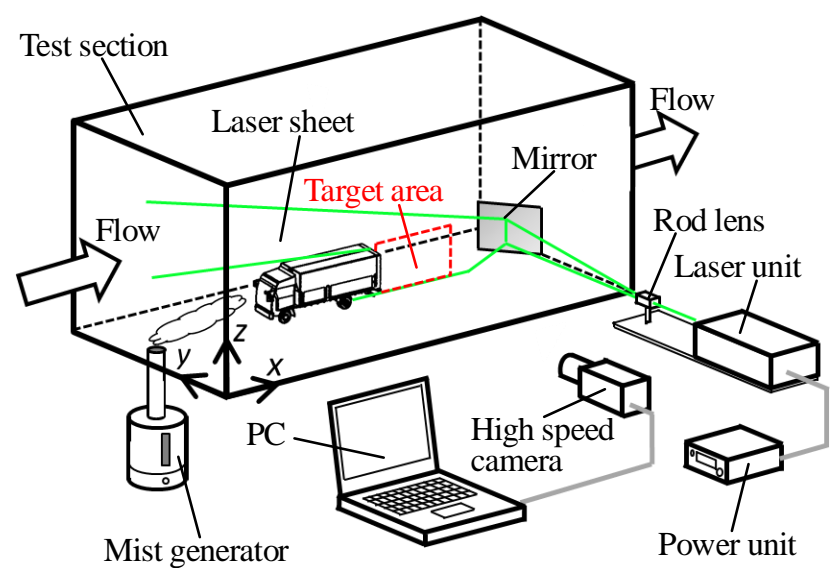

Fig. 5 Schematic diagram of PIV measurement in the stream-wise plane behind the truck model.

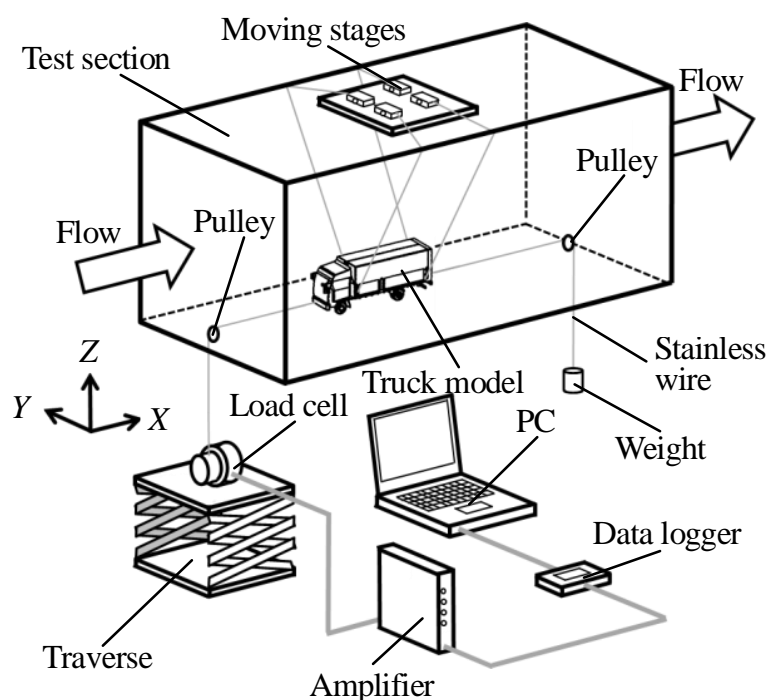

Fig. 4 Schematic diagrams of measurement for drag.

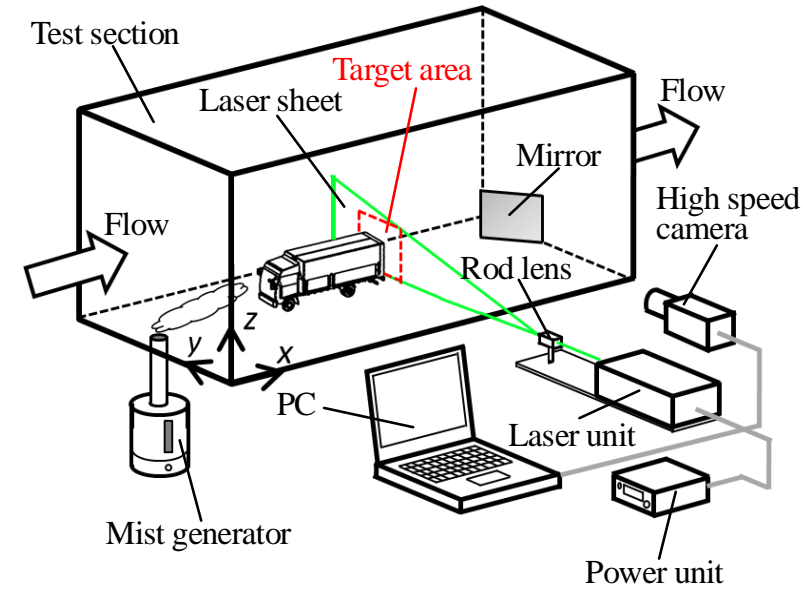

Fig. 6 Schematic diagram of PIV measurement in the stream-wise cross plane behind the truck model.

\section{5. 結果および考察}

\section{$5 \cdot 1 \quad 1 / 32$ スケールトラックモデルにおける風洞実験}

\section{$5 \cdot 1 \cdot 1$ 抗力測定結果}

図 7 に, 前方傾斜角 $\theta_{f}=5^{\circ}, 7^{\circ}, 10^{\circ}, 12^{\circ}$, 後方傾斜角 $\theta_{r}=3^{\circ}, 5^{\circ}, 7^{\circ}$ のウィンドディフレクタを装着した場合 の, 抗力の測定結果 (図 7 上段) および $C_{D}$ の算出結果（図 7 下段）を示す. 横軸はウィンドディフレクタの後 方傾斜角 $\left(\theta_{r}\right)$, 縦軸はウィンドディフレクタ非装着トラックモデルの抗力值を基準とした抗力変化率 $(\Delta d)$ と, 前面投影面積増加率 $(\Delta S)$ を考慮して算出した $C_{D}$ の変化率 $\left(\Delta C_{D}\right)$ である.

図 7 上段より, $\theta_{f}=5^{\circ}, 7^{\circ}, 10^{\circ}$ の場合は $\theta_{r}$ の増加に伴い抗力は減少し, ある点で最小值をとり, その後は $\theta_{r}$ の増加に伴い抗力は増加に転じる. $\theta_{f}=5^{\circ}$ の場合は $\theta_{r}=5^{\circ}$ で最小 $(\Delta d=-0.8 \%)$ となり, $\theta_{f}=7^{\circ}, 10^{\circ}$ の場合 
は $\theta_{r}=3^{\circ}$ で最小となり，それぞれ $\Delta d=-1.6 \%, \Delta d=-0.6 \%$ となった．しかし $\theta_{f}=12^{\circ}$ の場合は，測定を行っ たウィンドディフレクタ形状の中では抗力は隇少しなかった.

ここで，各 $\theta_{f}$ において最小值をとる $\theta_{r}$ の角度は， $\theta_{f}$ が大きくなる程小さくなっていく傾向にあると推測でき る. また $\theta_{f}$ に着目し，各 $\theta_{f}$ で最も抗力の減少した值を見ると， $\theta_{f}=7^{\circ}$ までは減少傾向にあり，それ以降は増 加傾向にあることがわかる.つまり， $\theta_{f}$ が小さい場合は, 流れ方向の変化が小さく, 十分な効果が得られず, $\theta_{f}$ が 大きすぎる場合は, 前面投影面積が大きくなり過ぎて, 抗力は増加する. この実験条件において, ウィンドディ フレクタの形状は $\theta_{f} \leqq 7^{\circ}$ が望ましい.

図 7 下段より, 測定を行ったウィンドディフレクタの全ての条件で $C_{D}$ は減少し, その変化率 $\Delta C_{D}$ は $\theta_{r}$ の増加 に伴って単調に減少した．また $\Delta C_{D}$ は，どの $\theta_{f}$ においても $\theta_{r}$ の増加に伴い近い值となり， $\theta_{f}$ の $C_{D}$ への依存性 は $\theta_{r}$ に比べると小さいことが分かる．測定を行った範囲では，ウィンドディフレクタの山が高くなるほど $C_{D}$ 低 減効果があると言える.

以上の抗力測定結果から， $C_{D}$ は殆どの条件で減少するものの，抗力は傾斜角度の条件によって増加する場合と 減少する場合がある. これは, $C_{D}$ の減少より前面投影面積 $\Delta S$ の増加が大きかったことが原因である. 従って, ウィンドディフレクタの最適形状を求めるには, $\Delta S$ と $\Delta C_{D}$ との兼ね合いが重要である.

次に, $\Delta S$ について考察する. 図 8 に, ウィンドディフレクタ装着による前面投影面積増加率 $(\Delta S)$ と抗力変化 率 $(\Delta d)$ の関係を示す．ここで，横軸は前面投影面積増加率 $(\Delta S)$, 縦軸は抗力変化率 $(\Delta d)$ を示す.

図 8 より，抗力が減少したウィンドディフレクタ形状は $\Delta S$ が $11 \%$ 以下に分布していることが分かる. $\Delta S$ が $11 \%$ を超えた形状に関しては，測定を行った形状の範囲内では抗力は殆ど変化しないか，もしくは増加した．従 って, ウィンドディフレクタ形状を決める上で, $\Delta S$ が $11 \%$ 以下が推奨值である. なお今回の実験で得られた抗 力が最も低減したウィンドディフレクタ形状は, $\theta_{f}=7^{\circ}$ かつ $\theta_{r}=3^{\circ}$ で,$\Delta S=8.2 \%$ であった.

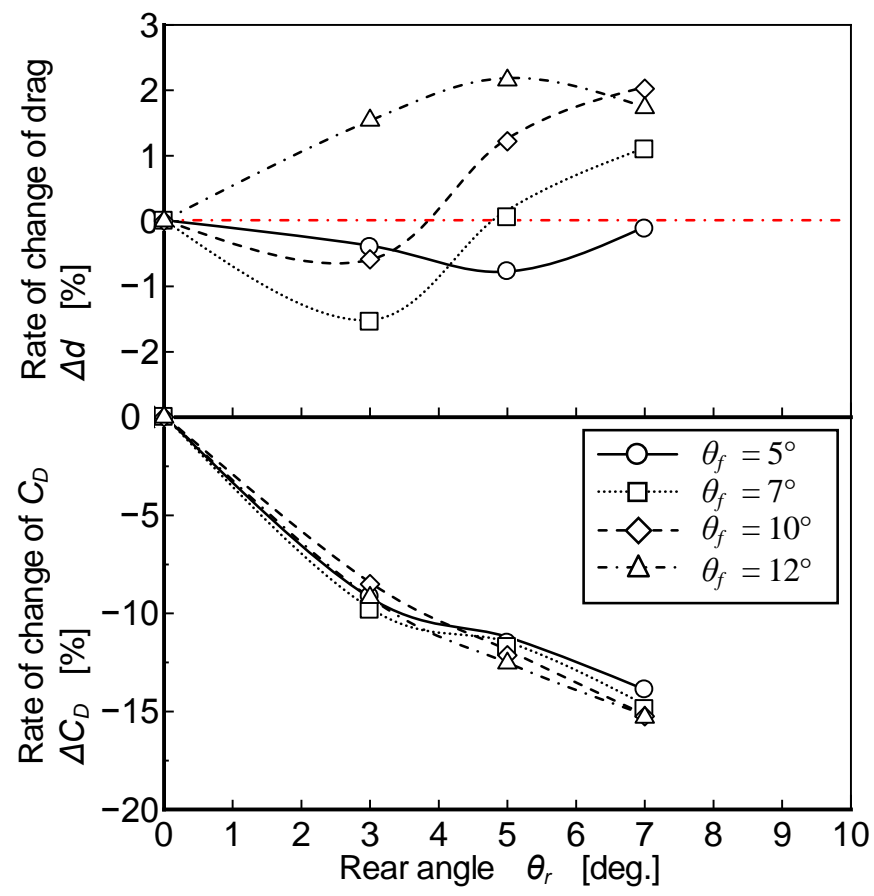

Fig.7 Measured results of rate of change of drag and $C_{D}$ against rear angle of wind deflector. $C_{D}$ is decreasing by increasing rear angle of wind deflector. Drag is also decreasing by increasing of rear angle, but drag increases when the rear angle is too big.

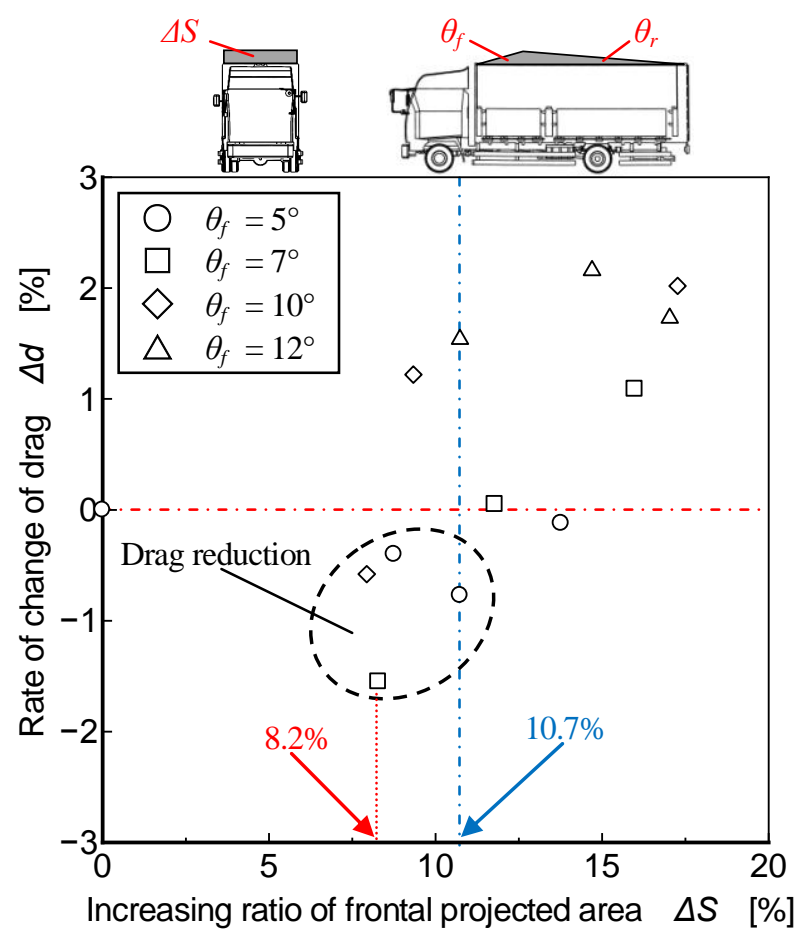

Fig.8 Measured results of rate of change of drag against frontal projected area of wind deflector.

Conditions that drag decreases is $\Delta S=10.7 \%$. And condition that drag decreases most is $\Delta S=8.2 \%$. 


\section{$5 \cdot 1 \cdot 2$ PIV 計測による流れの可視化結果}

図 9 に, 1 / 32 スケールトラックモデル後方 $X-Z$ 断面の流速ベクトル図を示寸. 図 9 (a) はウィンドディフレ クタ非装着, 図 9(b) は図 7 の抗力測定結果で最も抗力が減少した $\theta_{f}=7^{\circ}$ かつ $\theta_{r}=3^{\circ}$ のウィンドディフレクタを 装着した場合である。レーザ照射範囲の都合上，上下 2 分割で測定を行い繋ぎ合わせた結果を示す。この 2 分割 の測定範囲では，同時刻の測定結果ではないものの，画像平均枚数は同一とした，なお流速べクトルのカラース ケールは $X$ 成分の流速強度である.

図 9(a) より，トラックモデル後方には，大規模な再循環渦が形成されていることがわかる．車体床下から後方 へと巻き上げられた流れは，荷室背面近傍に渦を形成し，さらに荷室上部上端まで上昇する (矢印(1). 荷室上部 上端は主流速度に近い流れのため，下部から巻き上げられた流れはここで剥離し，剥離した主流と共に徐々に降 下しながら車体後方へと流れていく（矢印(2)）．今回，測定範囲の都合上，剥離流れの風洞床面への再付着点の測 定は出来なかった，再付着点よりも車体側では流れの逆流（矢印(3)）が起こり，車体床下からの巻き上げる流れ

（矢印(1)）と合流し，上昇し，広範囲に見ると車体後方に大規模な再循環流れの形成が見られる.

図 9 (b) より, $\theta_{f}=7^{\circ}$ かつ $\theta_{r}=3^{\circ}$ のウィンドディフレクタを装着した場合を見ると, ウィンドディフレクタ装 着により，トラックモデル後方のおおまかな流れパターンは変わらないが，渦の大きさや剥離角度に差異が現れ た. まず，車体床下から巻き上げる流れ（矢印(4)）がウィンドディフレクタ非装着の場合と比べると，より荷室 近傍で流れが巻き上がっており，荷室背面近傍に形成寸る渦も小規模になっていることがわかる．さらに，荷室 後部上端からの流れの剥離角度も, 非装着時（破線矢印(2)）と比べ下向き（矢印(5)）に変わることにより，車体 後方に形成される再循環領域の縮小が確認出来る。 そのため, 図中右上の剥離流れ上部（領域(6)）にも流速が高 い領域があり，これはウィンドディフレクタの効果により，車体後部の再循環流れが縮小したからである.

次に，トラックモデル後方 $Y-Z$ 断面における PIV 計測を行った. 図 10 (a) にウィンドディフレクタ非装着の 場合, 図 10 (b) に $\theta_{f}=7^{\circ}$ かつ $\theta_{r}=3^{\circ}$ のウィンドディフレクタを装着した場合の流速ベクトル図を示す. なお, 測定位置は，トラックの車体背面から $60 \mathrm{~mm}$ 後方の位置であり，流速ベクトルのカラースケールは，Z成分の流 速強度である. なお，こちらも図 9 に示した結果と同様に，上下 2 分割で測定を行い繋ぎ合わせた結果である.

図 10 (a) より，トラックモデル後方 $Y-Z$ 断面の流れは，下部から上昇流を形成していることがわかる.さらに 図中の中央部付近で流速が増加しているが，この流速増加は，図 9(a) に示したモデル下部から巻き上げるような 流れによるものと思われる. さらに，図中上部付近に，上昇流と下降流の境界（破線）があるのも見て取れる.

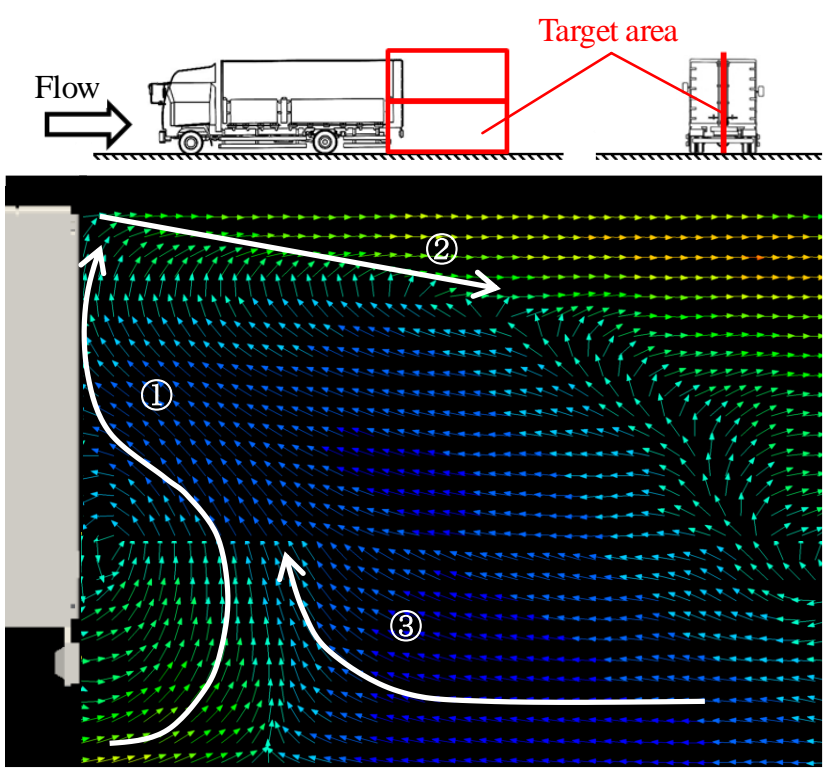

(a) Without wind deflector

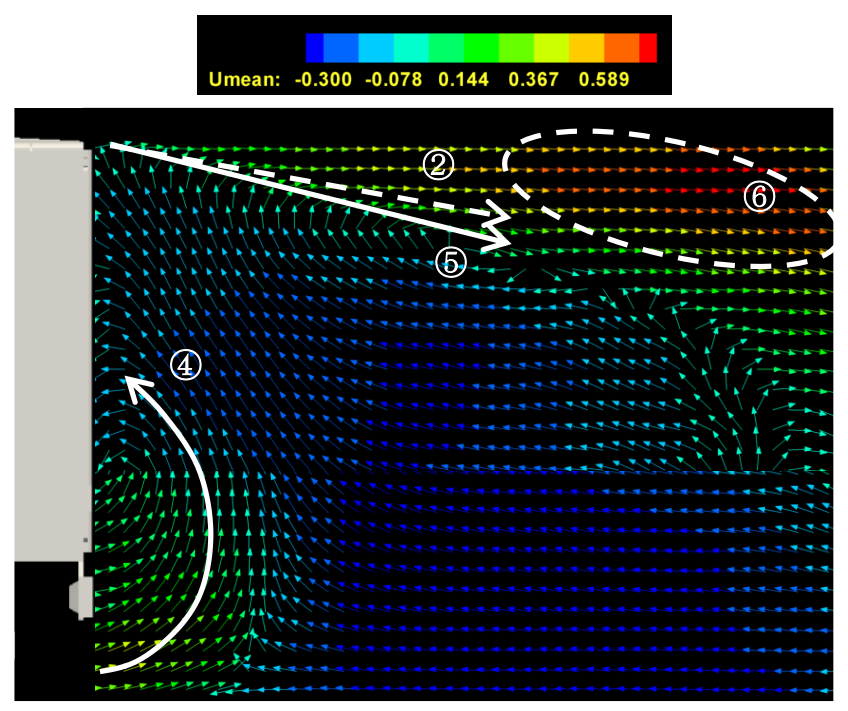

(b) With wind deflector $\left(\theta_{f}=7^{\circ}\right.$ and $\left.\theta_{r}=3^{\circ}\right)$

Fig.9 Comparison of velocity vectors behind truck model ( $X-Z$ plane). The flow direction from the tip of the container changes by the wind deflector. As a result, the size of the wake becomes small. 
図 10 (b) より, ウィンドディフレクタを装着した場合, 図中の中央部に発生する上昇流の流速が低下し, 特に, 中心部の流速低下が確認出来る. さらに, 図中上部の上昇流と下降流の境界も下方向に遷移していることもわか り, これは図 9 に示した, トラック後部上端からの剥離流れが下方向への遷移したことによる. また下降流に着 目寸ると，車体中心部付近でより流れが下降していることもわかり， ウィンドディフレクタが車体後部上端から の剥離流れに及ぼす特性の一つとして，車体中心部の流れをより下向きに遷移させていることがわかる.

以上のように，ウィンドディフレクタを装着した場合， $Y-Z$ 面における荷室後面の中心付近の流速が下がり， $X-Z$ 面における荷室上部上端からの流れの剥離方向が下方向へと遷移していることから, トラック車体後方に発 生する再循環領域が縮小していることが確認された.
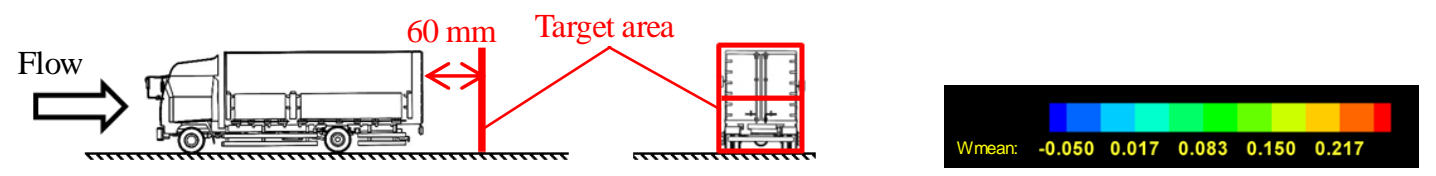

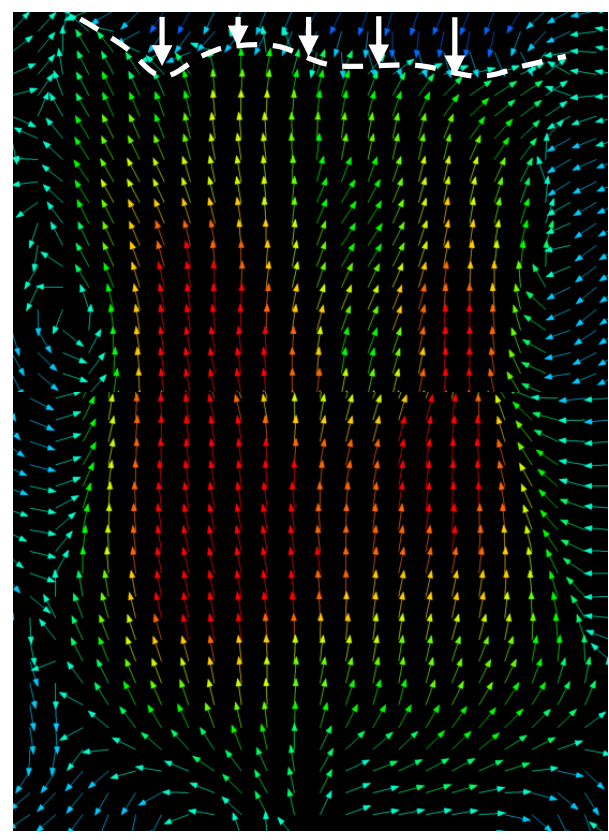

(a) Without wind deflector

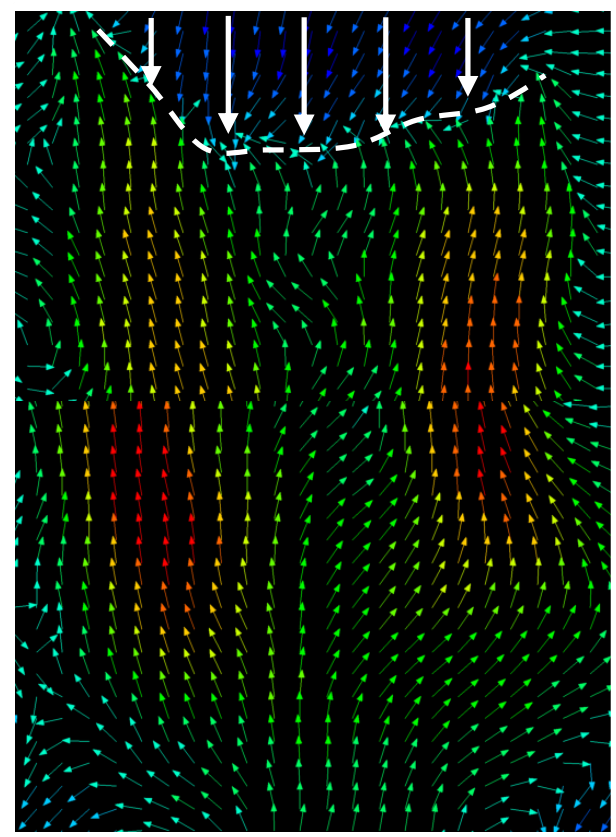

(b) With wind deflector $\left(\theta_{f}=7^{\circ}\right.$ and $\left.\theta_{r}=3^{\circ}\right)$

Fig.10 Comparison of velocity vectors behind truck model ( $X$ - $Y$ plane). Downstream from the tip of the container becomes strong by the wind deflector. Then velocity at upstream becomes weak.

\section{$5 \cdot 2$ 実車スケールトラックモデルにおける数值流体計算}

\section{$5 \cdot 2 \cdot 1$ 数值流体計算による抗力計算結果}

図 11 に, 前方傾斜角 $\theta_{f}=5^{\circ}, 7^{\circ}, 10^{\circ}, 12^{\circ}, 15^{\circ}, 17^{\circ}$, 後方傾斜角 $\theta_{r}=1^{\circ}, 2^{\circ}, 3^{\circ}, 5^{\circ}, 7^{\circ}, 10^{\circ}$ のウィンドディ フレクタを装着した場合の, 実車走行条件で行った抗力計算結果 (図 11 上段), および $C_{D}$ 計算結果 (図 11 下段) を示す. 横軸はウィンドディフレクタの後方傾斜角 $\left(\theta_{r}\right)$, 縦軸はウィンドディフレクタ非装着のトラックモデル の抗力值を基準とした抗力変化率 $(\Delta d)$, および $C_{D}$ 変化率 $\left(\Delta C_{D}\right)$ を示す. 各プロットの組み合わせは, $\theta_{f}=5^{\circ}$, $7^{\circ}$ の場合は $\theta_{r}=3^{\circ}, 5^{\circ}, 7^{\circ}, 10^{\circ}$ で 8 パターン, $\theta_{f}=10^{\circ}, 12^{\circ}, 15^{\circ}, 17^{\circ}$ の場合は $\theta_{r}=1^{\circ}, 2^{\circ}, 3^{\circ}, 5^{\circ}, 7^{\circ}, 10^{\circ}$ で 24 パターン, さらに $\theta_{r}=0^{\circ}, \theta_{f}=0^{\circ}$ のウィンドディフレクタ非装着の場合を含め, 計 33 パターンである.

図 11 上段より, 抗力は $\theta_{r}$ の増加に伴い減少し, $\theta_{r}=3^{\circ}$ で最小となり, その後は $\theta_{r}$ の増加と共に抗力も増加 した. この傾向は図 7 に示した抗力測定結果と同様の傾向であるが，数值計算の場合はどの $\theta_{f}$ においても $\theta_{r}=$ 3。で抗力最小となった.

また計算結果では， $\theta_{f}$ の増加に伴い，その減少率の絶対值およびグラフの傾きが大きくなっていることもわか る。つまり， $\theta_{f}$ が増加するにつれて，その減少率も増加するが，抗力が減少寸る $\theta_{r}$ の範囲は狭まるため，より局 所的な減少特性になっていくと考えられる. さらに, $\Delta d$ が増加する $\left(0 \%\right.$ 以上になる）場合の $\theta_{r}$ も小さい方に 
遷移していることからもこのことが言える. なお，最も抗力が低減した形状は， $\theta_{f}=17^{\circ}$ かつ $\theta_{r}=3^{\circ}$ で，抗力 低減率は $3.4 \%$ \%゙った. 1/32 スケールかつ低流速条件での抗力測定結果と比較すると, 検証条件が異なること からその減少率の絶対值は異なる. また, 図 7 上段の抗力測定結果では $\theta_{f}>7^{\circ}$ で抗力が減少しなくなり, 増加 していく傾向を見せたが, 数值計算結果ではそれは見られず, 計算を行った範囲では, $\theta_{f}$ の増加に伴い, 抗力の 減少值は大きくなった。 これは, 実験と計算では $R e$ 数の条件が異なり, より高 $R e$ 条件の計算ではウィンドディ フレクタの頂点に対する流れの追従性が増し, 抗力減少の極值にあたる $\theta_{f}$ の限界が高くなったと考えられる. ただしその極值は $\theta_{f}=17^{\circ}$ 以上に確実に存在すると推測できる.

図 11 下段より, 図 7 下段と同様に $C_{D}$ は $\theta_{r}$ の増加に伴い減少していく.さらに $\theta_{r}$ を増加させていくにつれ, その減少の傾きも小さくなり， $\theta_{f}$ の増加に伴い減少率の絶対值が大きくなっている.さらに $\theta_{r}$ を一定とした場 合, $C_{D}$ は $\theta_{f}$ の増加に伴いその変化幅が小さくなっていく傾向にあり, 計算を行った範囲内では, $\theta_{f}=17^{\circ}$ で減 少率の絶対值はほぼ収束しているように見える.

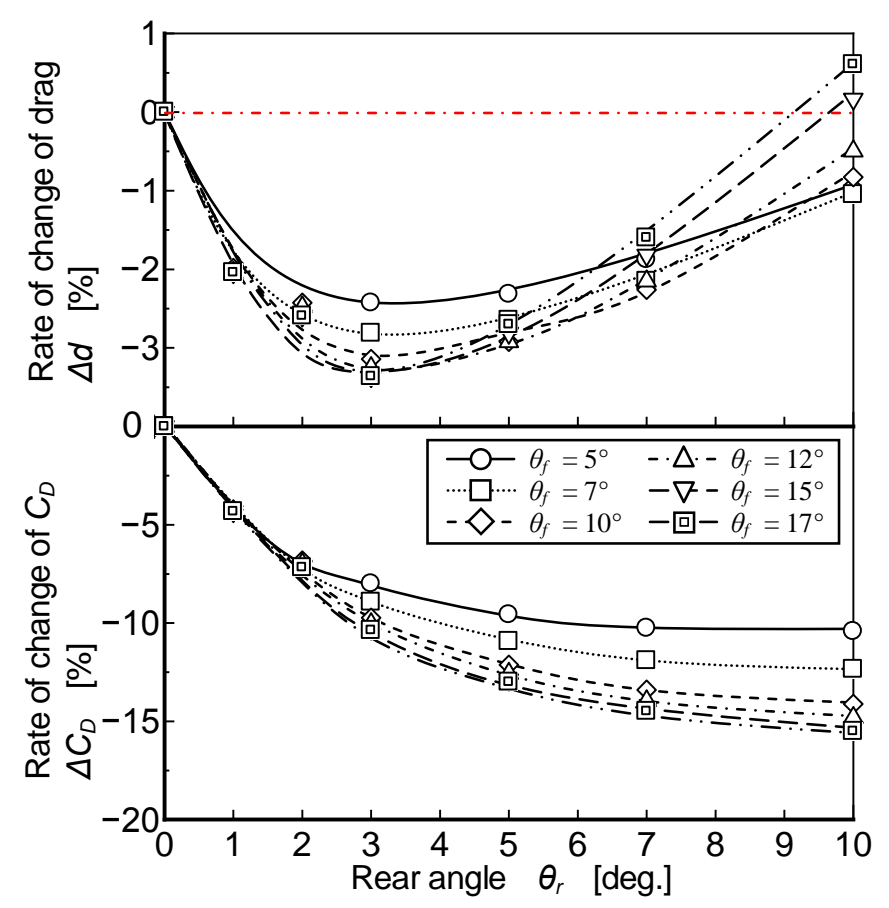

Fig.11 Calculated results of rate of change of drag and $C_{D}$ against rear angle of wind deflector. By increasing of $\theta_{r}$, drag decreases until $3^{\circ}$, but increases over $3^{\circ}$. $\Delta C_{D}$ decreases by increasing of $\theta_{r}$.

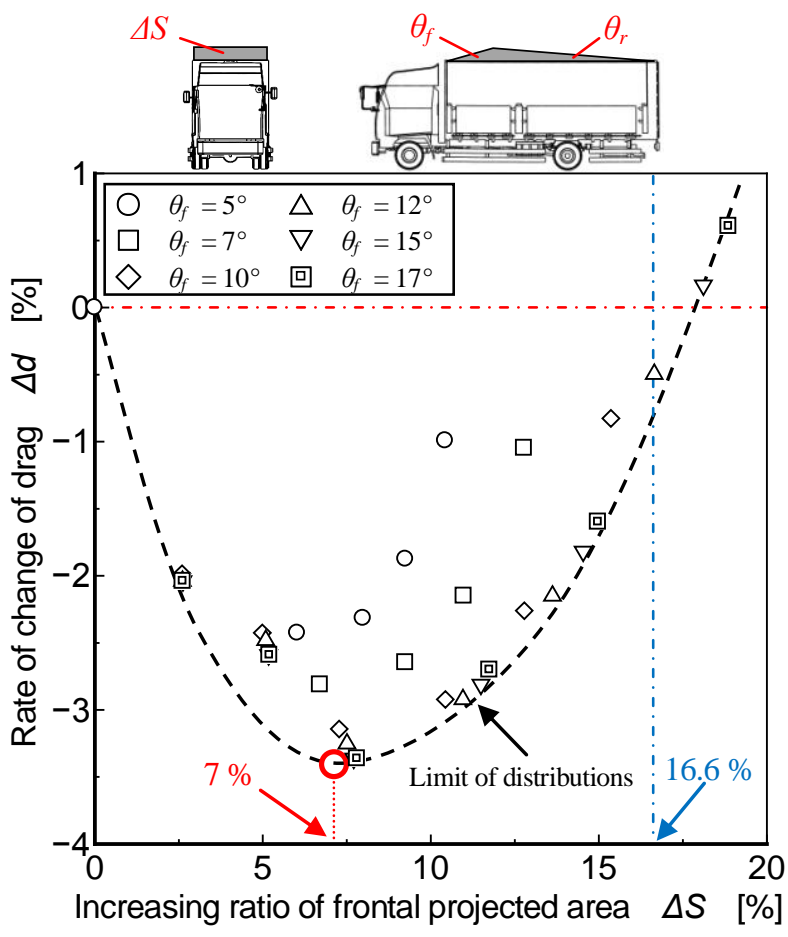

Fig.12 Calculated results of rate of change of drag against frontal projected area of wind deflector. The shape to reduce drag most is $\Delta S=7 \%$.

図 12 に, 各ウィンドディフレクタ装着による, トラックモデルの前面投影面積増加率と抗力変化率の関係を示 す. 横軸は前面投影面積増加率 $(\Delta S)$, 縦軸は抗力変化率 $(\Delta d)$ を示す.

図 12 より, 実車走行条件による計算結果は, 計算を行ったほとんどのウィンドディフレクタ形状で, 抗力は減 少した. また，抗力が低減したウィンドディフレクタ形状は， $\Delta S$ が $17 \%$ 以下に分布した. $\Delta S$ が $17 \%$ を超えた 形状に関しては，測定を行った形状の範囲内では抗力は増加した．さらに，各 $\Delta S$ に対して最も抗力が低いプロ ットを破線で結ぶと, 図中にある曲線になり, これが抗力低減の限界曲線として考えることが出来る. さらにこ の曲線から, 最も抗力が減少する $\Delta S$ を推測すると $7 \%$ 付近となり, 計算を行った $\theta_{f}=17^{\circ}$ かつ $\theta_{r}=3^{\circ}$ の形状 は，極值付近に位置していることが言える．さらに，図 12 の結果より，最も抗力が減少した $\Delta S$ を見ると，図 8 に示した $11 \%$ 以内に位置しており, 図 8 で, 最も抗力の低減した形状は $\Delta S=8.2 \%$ であることからも, 計算結 果の最適条件は実験值とも近い值になった。 これは，レイノルズ数が大きく異なる場合でも，ウィンドディフレ クタの最適形状として，前面投影面積増加率に関しては概小近い值になることを示唆している. 


\section{$5 \cdot 2 \cdot 2$ 数值流体計算による流れの解析結果}

図 13 に，実車スケールトラックモデル後方の流速ベクトル図を示す. 図 13 (a) は，ウィンドディフレクタ非 装着モデル, 図 13 (b) は, 図 11 にて最小の抗力を示した $\theta_{f}=17^{\circ}$ かつ $\theta_{r}=3^{\circ}$ のウィンドディフレクタを装着 したものである.

図 13 (a) より，トラックモデル後方には，床下から巻き上げるような流れ (矢印(7)), 荷室背面近傍を上昇す る流れ (矢印(8)), 荷室上端から後方へと剥離する流れ（矢印9)， そして後方再付着点から逆流する流れ（矢印 (10)）により大規模な再循環流れが形成されている.さらにトラックモデル後方下部，および剥離流れと逆流流れ の境界に渦（領域111) が発生している。これらの流れパターンは，図９の小スケールモデル PIV 計測結果とほぼ 同様の流れパターンであるが，巻き上げ流れの大きさや渦の規模などに差異がある.

図 13 (b) より，ウィンドディフレクタを装着した場合を見ると，荷室上端からの流れ（矢印12）は非装着（破 線矢印(9)）と比べると剥離方向が下方向に遷移していることがわかり，図 9 にも示したように，図中右上の領域

(領域(13)）で流速が高く，主流がより下方へと遷移したことがわかる.さらに，トラックモデル後方上部に発生 する渦（領域(14）の発生位置に着目すると， ウィンドディフレクタ装着により，渦の発生位置がよりトラックモ デル近傍へ遷移していることがわかる，さらに車体下からの巻き上げにより発生する渦（領域(15)，(16）の位置は ウィンドディフレクタ装着により遠方に遷移した.

図 14 に，3 次元可視化ソフト（Kitware 社，Paraview ver.3.8.1）により表示した，トラックモデル周り流れの流 跡線を示す. 図 14 (a) は, ウィンドディフレクタ非装着モデル, 図 14(b) は, $\theta_{f}=17^{\circ}$ かつ $\theta_{r}=3^{\circ}$ のウィンド ディフレクタを装着した場合を示す.

図 14 (a) より，トラックモデル後方に発生する大規模な渦の構成には，床下を通過した流れが大きく関わって いることがわかり，トラックモデル上部を通過した流れは，荷室後部上端で剥離した後，再循環領域の負圧に引 つ張られるように下向きに方向を変え, 後方へと流れている. 一方, 図 14(b)のウィンドディフレクタを装着した 場合，荷室後部上端からの剥離角度がより下方向に遷移し，さらにトラックモデル後方の巻き上げ流れの縮小も 確認出来る. つまり，ウィンドディフレクタの装着は，トラックモデル後方下部の巻き上げ流れに直接的には影 響しないが，トラックモデル後部上端剥離方向の下方向への遷移により，剥離流れが車体下からの巻き上げ流れ を抑制しているように見える.

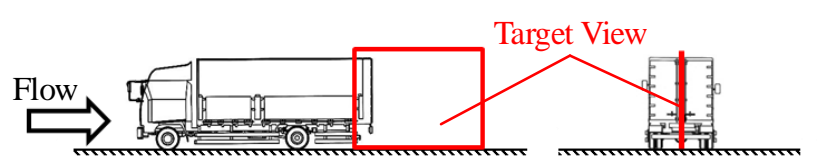

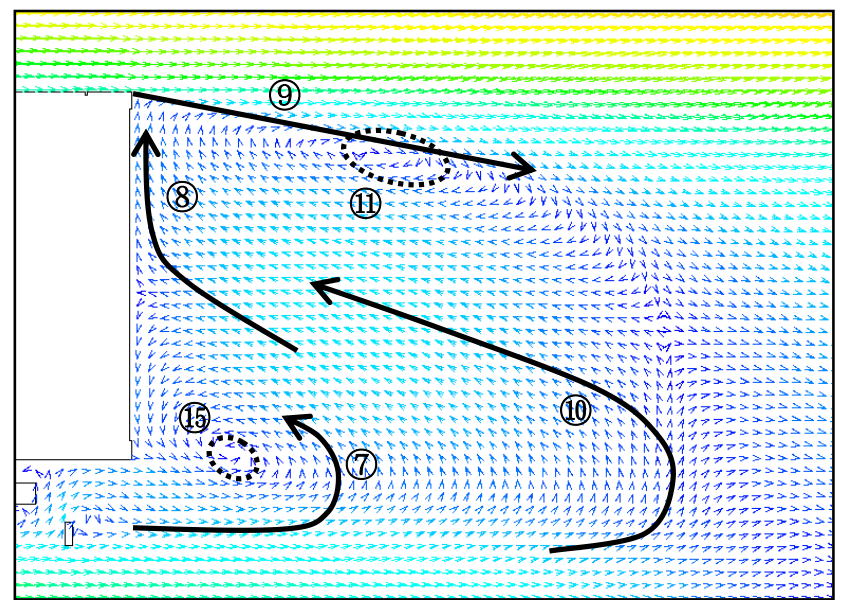

(a) Without wind deflector

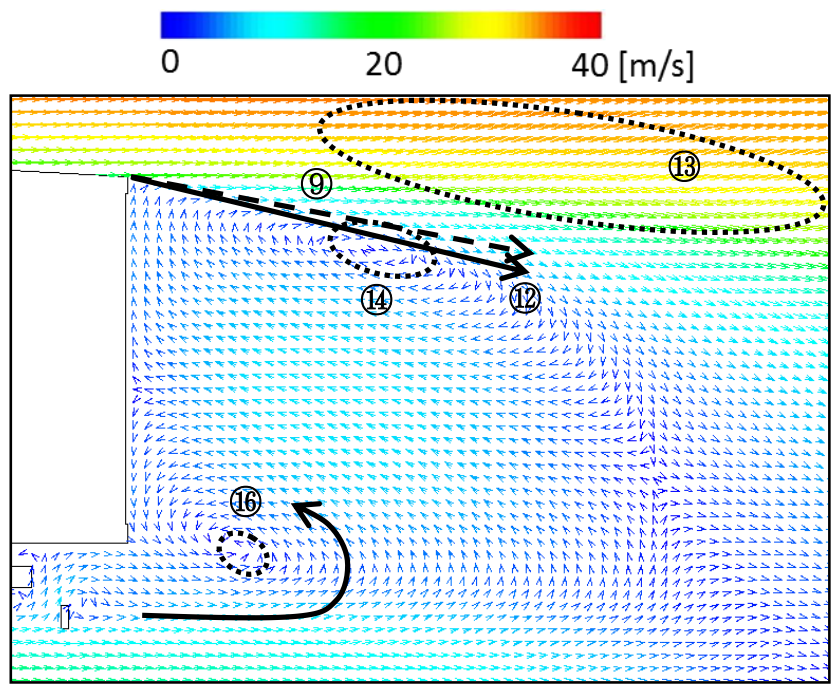

(b) With wind deflector $\left(\theta_{f}=17^{\circ}\right.$ and $\left.\theta_{r}=3^{\circ}\right)$

Fig.13 Comparison of velocity vectors behind truck model ( $X-Z$ plane). A difference of flow by attaching wind deflector or not is no.9 and 12. And the vortex positions are moved from no. 15 to 16 , and from no.11 to 14 . 


\section{$5 \cdot 2 \cdot 3$ 数值流体計算による圧力解析結果}

図 15 に，実車スケールトラックモデルの背面にかかる圧力分布図を示す. 図 15(a) は，ウィンドディフレクタ 非装着の場合, 図 15(b) は, $\theta_{f}=17^{\circ}$ かつ $\theta_{r}=3^{\circ}$ のウィンドディフレクタを装着した場合を示す.

図 15(a) より，トラック背面にかかる圧力は車体前面を基準として負の圧力であり，進行方向に反して，後ろ 向きに引つ張る力が生じている. トラックモデル背面中央部と外側付近を比べると，中央部の方が圧力が高い. これは，再循環流れの逆流が背面に当たり，剥離する荷室背面周りと比べ圧力を高めているからである.

図 15(b)のウィンドディフレクタを装着した場合，ウィンドディフレクタ非装着モデルと比ベ，全体的に 15〜 $20 \mathrm{~Pa}$ 背面圧力が増加している. 物体に働く圧力抵抗は, 物体前後に加わる圧力差に因ることから, 背面圧力が高 いほど圧力抵抗は小さくなる. これより，ウィンドディフレクタ装着による抗力低減は，トラックモデル後方渦 の縮小による，トラックモデル背面圧力の増加が起因していると言える.

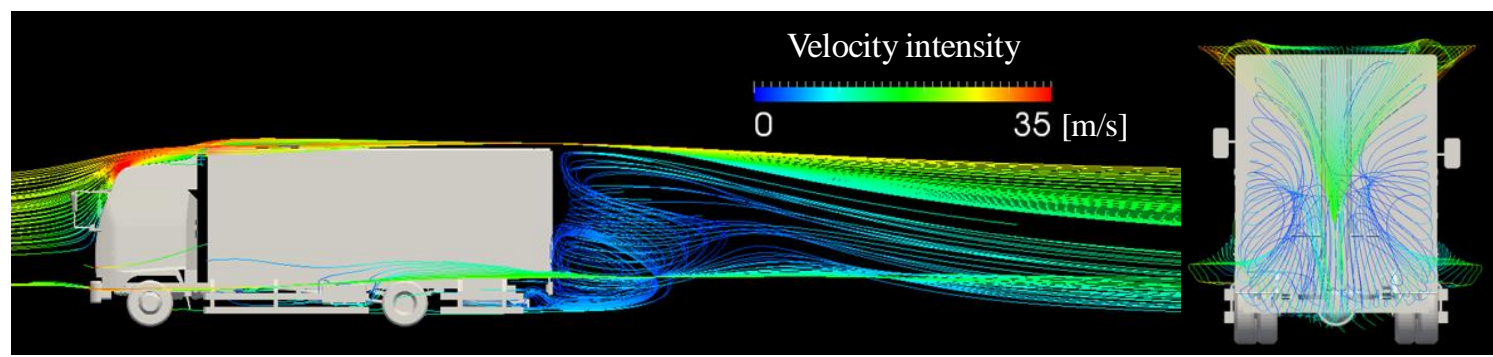

(a) Without wind deflector

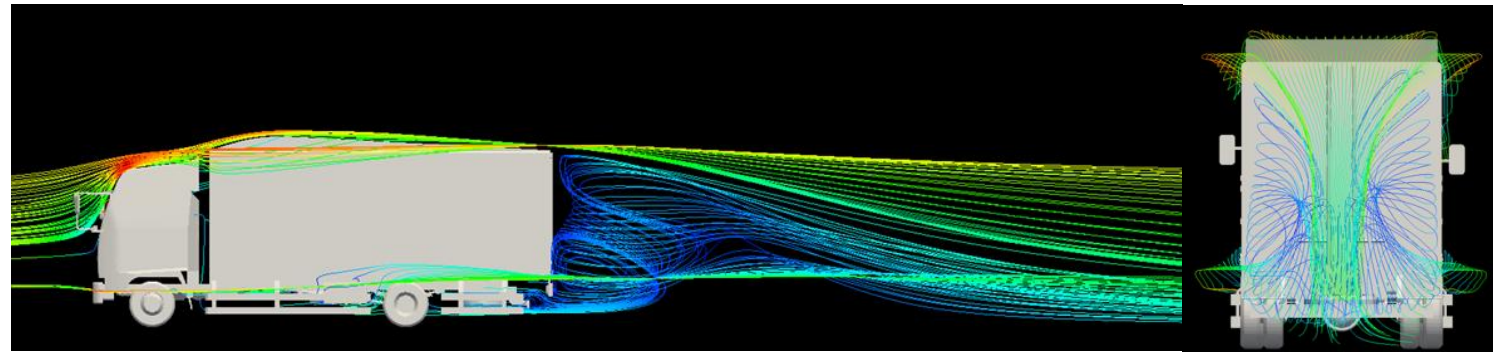

(b) With wind deflector $\left(\theta_{f}=17^{\circ}\right.$ and $\left.\quad \theta_{r}=3^{\circ}\right)$

Fig.14 Comparison of the path lines around the truck model. The flow over the truck model changes the direction by the wind deflector. And the separation flow from the tip of the container goes to low direction.

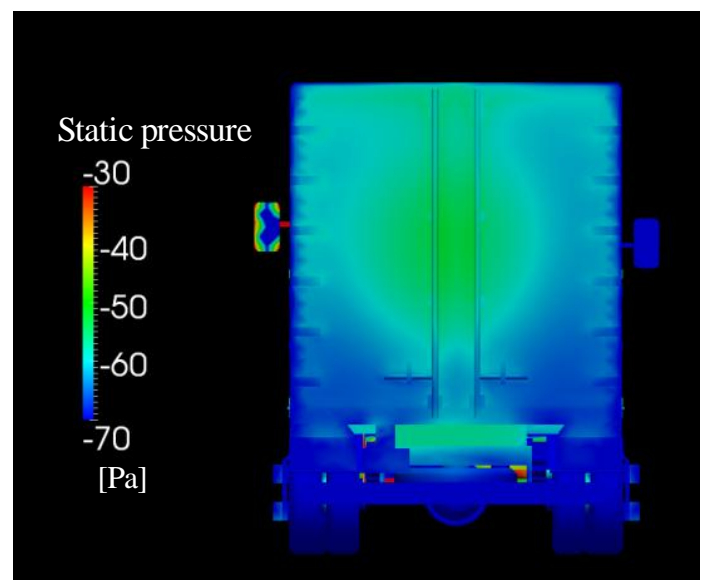

(a) Without wind deflector

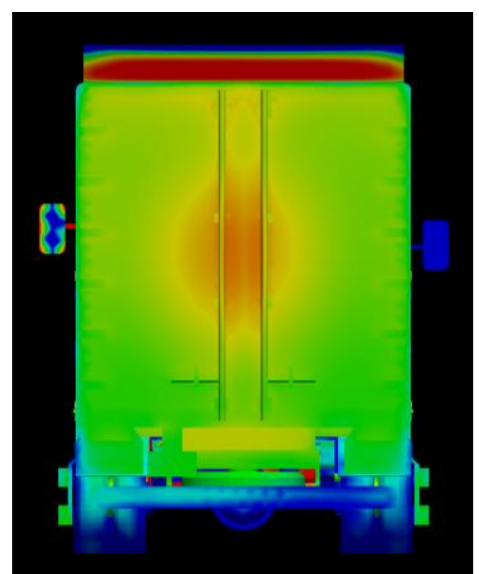

(b) With wind deflector $\left(\theta_{f}=17^{\circ}\right.$ and $\left.\theta_{r}=3^{\circ}\right)$

Fig.15 Comparison of the static pressures behind the truck model. The static pressure behind the truck model is increased with wind deflector. This causes the drag reduction of the truck model. 


\section{6. 結 言}

本研究では, トラックの抗力低減を目的として, 荷室上部に設置寸るウィンドディフレクタを提案し, その効 果の検証および最適形状の検討のため, $1 / 32$ スケールモデルを用いた風洞実験, および実車スケールモデルを用 いた数值流体解析を行った. 得られた結果を以下に示す.

(1) 1 / 32 スケールモデルで行った抗力測定では, 抗力低減には, 抗力係数変化率 $\Delta C_{D}$ と前面投影面積増加率 $\Delta S$ の兼ね合いが重要であり, 最も抗力が低減した形状は前方傾斜角 $\theta_{f}=7^{\circ}$ かつ後方傾斜角 $\theta_{r}=3^{\circ}$ で, $\Delta S=$ $8.2 \%$, 抗力の低減率は $1.6 \%$ であった. $\theta_{f}$ および $\theta_{r}$ はそれ以上大きくなると, $\Delta C_{D}$ の減少よりも $\Delta S$ の増加 が上回り, 抗力は増加した.

(2) 1 / 32 スケールモデルで行った PIV 計測による流れの可視化では，トラックモデル後方に，大規模な再循環 流れの形成が見られた．ウィンドディフレクタを装着すると，トラックモデル後部上端からの流れの剥離方 向が下方へ遷移し，トラックモデル後方の再循環領域は縮小することを確認した.

(3) 実車スケールモデルを対象にした数值流体計算では, 計算を行った殆どのウィンドディフレクタ形状で抗力 は減少し, 最も抗力が低減した形状は, $\theta_{f}=17^{\circ}$ かつ $\theta_{r}=3^{\circ}$ で, $\Delta S=7 \%$, 抗力の低減率は $3.4 \%$ となった. $1 / 32$ スケールモデルの測定結果と比較し, レイノルズ数が大きく異なる場合でも, ウィンドディフレクタ

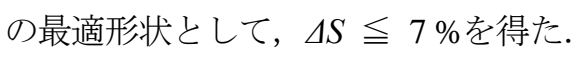

(4) 実車スケールモデルを対象にした数值流体計算の流れパターンは，1 / 32 スケールモデルの PIV 計測結果と 似た結果であった。計算で最も抗力が低減した $\theta_{f}=17^{\circ}$ かつ $\theta_{r}=3^{\circ}$ のウィンドディフレクタ装着により, トラックモデル荷室背面の圧力は 15〜20 Pa 増加し，それが抗力低減の主因である.

\section{文献}

Browand, F. and Radovich, C., Fuel savings by means of flaps attached to the base of a trailer: Field test results, SAE Technical Paper Series (2005), Paper No. 2005-01-1016.

Ishima, T., Nomura, T., Takahashi, Y. and Obokata, T., Analysis on in-cylinder flow by means of LDA, PIV and numerical simulation under steady state flow condition, SAE Technical Paper Series (2008), Paper No.2008-01-0538.

Ishima, T., Takahashi, Y., Okado, H., Baba, Y. and Obokata, T., 3D-PIV measurement and visualization of streamlines around a standard SAE vehicle model, SAE Technical Paper Series (2011), Paper No. 2011-01-0161.

環境省, 温室効果ガスインベントリ， 2011 年度（平成 23 年度）の温室効果ガス排出量（確定值）について, $<$ http://www.env.go.jp/earth/ondanka/ghg/2011ghg.pdf>, (参照日 2014 年 3 月 29 日).

農沢隆秀, 佐藤浩, 自動車形状を持つにぶい物体の空気抵抗低減に関する形状パラメータの研究（第 1 報, 箱型 車体の空気抵抗低減と後流構造), 日本機械学会論文集 B 編, Vol.58, No.556 (1992), pp.64-69.

高橋易資，野村友和，石間経章，小保方富夫，直線直交格子を用いたパーシャルセル法による筒内定常流の計算 と PIV 計測による検証，日本機械学会論文集 B 編, Vol.71, No.706 (2005), pp.194-201.

Takahashi, Y., Gokan, Y., Inayoshi, M., Ishima, T. and Obokata, T., Numerical prediction of heat transfer coefficient by Karman's analogy and an application for air - cooled motorcycle engines, Journal of Fluid Science and Technology, Vol.2, No.3, Special Issue on Advanced Turbulence Research (2007), pp.570-581.

Takahashi, Y., Kurakawa, Y., Sugita, H., Ishima, T. and Obokata, T., CFD analysis of airflow around the rider of a motorcycle for rider comfort improvement, SAE Technical Paper Series (2009), Paper No. 2009-01-1155.

土田典之, 芦田泰一, 風間徹, 大型トラック用低空気抵抗荷台の開発, 自動車技術会学術講演会前刷集, Vol.153, No.10 (2010), pp.17-20.

\section{References}

Browand, F. and Radovich, C., Fuel savings by means of flaps attached to the base of a trailer: Field test results, SAE Technical Paper Series (2005), Paper No. 2005-01-1016. 
Ishima, T., Nomura, T., Takahashi, Y. and Obokata, T., Analysis on in-cylinder flow by means of LDA, PIV and numerical simulation under steady state flow condition, SAE Technical Paper Series (2008), Paper No.2008-01-0538.

Ishima, T., Takahashi, Y., Okado, H., Baba, Y. and Obokata, T., 3D-PIV measurement and visualization of streamlines around a standard SAE vehicle model, SAE Technical Paper Series (2011), Paper No. 2011-01-0161.

Ministry of the environment government of Japan, Japan's national greenhouse gas emissions in fiscal year 2011, Ministry of the environment government of Japan (online), available from <http://www.env.go.jp/earth/ondanka/ghg/ 2011ghg.pdf>, (accessed on 29 March, 2014) (in Japanese) .

Nouzawa, T. and Sato, H., Analysis of effective configuration parameter for reducing aerodynamic drag of bluff body such as vehicle $\left(1^{\text {st }}\right.$ report, aerodynamic drag and wake structure of box type vehicle), Transactions of the Japan Society of Mechanical Engineers, Series B, Vol.58, No.556 (1992), pp.64-69 (in Japanese).

Takahashi, Y., Nomura, T., Ishima, T. and Obokata, T., Numerical analysis on steady state in-cylinder-flow by Partial cells in cartesian coordinate method and verification with PIV mesurement, Transactions of the Japan Society of Mechanical Engineers, Series B, Vol.71, No.706 (2005), pp.194-201 (in Japanese).

Takahashi, Y., Gokan, Y., Inayoshi, M., Ishima, T. and Obokata, T., Numerical prediction of heat transfer coefficient by Karman's analogy and an application for air - cooled motorcycle engines, Journal of Fluid Science and Technology, Vol.2, No.3, Special Issue on Advanced Turbulence Research (2007), pp.570-581.

Takahashi, Y., Kurakawa, Y., Sugita, H., Ishima, T. and Obokata, T., CFD analysis of airflow around the rider of a motorcycle for rider comfort improvement, SAE Technical Paper Series (2009), Paper No. 2009-01-1155.

Tsuchida, N., Ashida, T. and Kazama, T., Development of aerodynamic van body for heavy duty truck, Proceedings of 2010 Annual Congress (Autumn) of Society of Automotive Engineers of Japan, Vol.153, No.10 (2010), pp.17-20 (in Japanese). 